\title{
ASSESMENT OF RECOMBINANT LINES OF MAIZE HYBRIDS FOR INBRED DEVELOPMENT
}

\author{
UtTam Chandel* BS Mankotia AND KS ThaKuR \\ CSK Himachal Pradesh Agricultural University, Shivalik Agricultural Research and Extension \\ Centre, Kangra-176001, India
}

Key words: Assessment, Recombinant lines, Maize hybrids, Inbred development

\begin{abstract}
Maize (Zea mays L.) breeders currently exploit genetically narrow-base populations by deriving the recombination lines from $\mathrm{F}_{2}$ of commercial single cross hybrids. A mating design was proposed for maize hybrid evaluation as source germplasm. The commercial single cross hybrids, Hi Shell, DKC 7074 and PMZ 4, developed by the commercial company, Monsanto, were evaluated for their usefulness as germplasm. According to mating design three criteria were used: the percentage of inbreeding depression, the general combining ability and the specific combining ability. PMZ 4 had a lower percentage (21.9) of inbreeding depression, which was also combined with positive general combining ability (7.5) and negative specific combining ability. The estimated percentage of inbreeding depression was greater in DKC 7074 (31.4) and in Hi Shell (25.3). DKC 7074 also had negative general combining ability (35.5), while Hi Shell had positive specific combining ability (75.0). Therefore, evaluation through mating design showed PMZ 4 possesses more desirable genes and that it's $\mathrm{F}_{2}$ may be a more profitable germplasm for developing elite inbred lines.
\end{abstract}

The plant breeder's choice of source germplasm determines the potential improvement for traits under selection in the breeding program (Fountain and Hallauer 1996). Source germplasm used by maize breeders for inbred development includes primarly $F_{2}$ (elite $\times$ elite inbred crosses), backcross and synthetic populations. An increased use of $F_{2}$ and backcross population since 1948 for second-cycle inbred development programs, with a corresponding rapid decline in the use of open-pollinated cultivars. Synthetic populations currently comprise about $45 \%$ of the germplasm used for maize inbred development, and breeders plan to increase the usage of synthetic populations (Hallauer 1990). Publicly and privately funded breeding programs have contributed to genetic improvement of maize hybrids in the United States: the former emphasizes genetic improvement of populations, whereas the latter emphasizes inbred development within $F_{2}$ and backcross populations. For a successful program of recycling breeding, the choice of the germplasm is the first priority (Duvick 1996). Current maize breeders prefer genetically narrowbase populations, including elite-line synthetics with a restricted genetic base, $F_{2}$ populations of single crosses and backcross populations (Hallauer 1979).

Synthetic maize populations are usually developed by intermating ten or more elite inbreds that may be related or unrelated. Evidence suggests that maize breeders emphasize selection within elite-line $F_{2}$ populations (Jenkins 1978, Bauman 1981). Although evidence suggests that the genetic base of maize breeding programs is becoming restricted, continued genetic progress has been realized in the development of hybrids (Duvick 1984, Russell 1991). Thus, breeder's interest has turned to relatively short-term projects for the improvement of narrow-base populations composed of elite germplasm. An approach for the evaluation of maize hybrids is proposed in the present study. It is based on mating designs that evaluate commercial single cross hybrids by estimating the $\mathrm{F}_{2}$ performance and its inbreeding depression; the general combining ability from

*Author for correspondence: <uttam_chandel@yahoo.co.in>. 
diallel crosses between maize hybrids and the specific combining ability from test crosses between commercial hybrids with an elite inbred line.

Three commercial Monsanto hybrids viz; Hi Shell, DKC 7074 and PMZ 4 well adapted to mill hill conditions of north-western Himalayas were used in the present study. Thus, these hybrids possessed an optimum combination of favorable alleles for this particular region. An elite inbred line CM 212 was used as a tester. All the experiments were conducted at the research farm of the SAREC, Kangra. Briefly, the following procedure was applied. In 2010, the mating design including selfing of the commercial hybrids, crossing of commercial hybrids with the tester and producing the diallel crosses excluding reciprocals between the commercial hybrids were attempted. In 2011, three single crosses hybrids along with their $F_{2}$ were evaluated in RBD with three replications. Similarly, these single cross hybrids were also evaluated in comparison with their diallel crosses and their test crosses with inbred line CM 212 in RBD with three replications. All experiments were subjected to growing conditions promoting high yield. Plant to plant distance was maintained at $20 \mathrm{~cm}$, whereas row to row spacing was $60 \mathrm{~cm}$. Observations were recorded on number of days from sowing to pollen shed, ears /plant, ear height $(\mathrm{cm})$, rows/ear, ear length $(\mathrm{cm})$ and grain yield/plant (g) at $15.0 \%$ grain moisture. The inbreeding depression of each $\mathrm{F}_{2}$ was calculated as the relative difference with regard to the commercial hybrid (Meghji et al. 1984). The GCA and SCA were estimated following Falconer (1989).

The commercial hybrid PMZ 4 showed less than 25\% inbreeding depression, while the others viz; Hi shell and DKC 7074 showed more than 25\% (Table 1). The percentage of inbreeding depression in traits (Table 2) showed higher values in ears/plant and ear length $(\mathrm{cm})$. These values indicate decrease prolificacy and cob size in $\mathrm{F}_{2}$. The total value of the percentage of inbreeding depression in morphological traits was lower in commercial hybrid PMZ 4. The diallel crosses showed positive general combining ability in the commercial hybrids PMZ 4 and Hi shell and negative specific combining ability in DKC 7074 and PMZ 4. The diallel crosses of hybrids had yields less than mid-parent performance, the test crosses out yielded the commercial hybrids and mid parent heterosis ranged from 57 - 124\% (Table 3). The diallel crosses showed positive general combining ability in the PMZ 4 and Hi Shell and negative specific combining ability in the DKC 7074 and PMZ 4.

Table 1. Grain yield (g/plant) in $F_{1}$ and $F_{2}$ generations, the yield in per cent relative to CM 212×V 341 and inbreeding depression of each maize hybrid.

\begin{tabular}{llll}
\hline Genotype & $\begin{array}{c}\text { Yield/plant } \\
(\mathrm{g})\end{array}$ & $\begin{array}{l}\text { Inbreeding } \\
\text { depression (\%) }\end{array}$ & $\begin{array}{l}\text { Yield relative to } \\
\mathrm{CM} 212 \times \mathrm{V} 341\end{array}$ \\
\hline Hi Shell & $\mathrm{F}_{\mathrm{I}} 1116$ & & 170.7 \\
& $\mathrm{~F}_{2} 833$ & 25.3 & 154.6 \\
DKC 7074 & $\mathrm{F}_{\mathrm{I}} 943$ & & 144.1 \\
& $\mathrm{~F}_{2} 647$ & 31.4 & 120.0 \\
PMZ 4 & $\mathrm{F}_{\mathrm{I}} 1113$ & & 170.2 \\
& $\mathrm{~F}_{2} 869$ & 21.9 & 161.2 \\
CM 212×V 341 & 654 & & 100 \\
(check) & & & \\
\hline
\end{tabular}

Proper choice of base population is a key to success in recycling breeding. $F_{2}$ generation of elite line crosses is the most commonly used parental germplasm (Bernardo 1996). The objective of the present study was to evaluate $\mathrm{F}_{2}$ generation of commercial hybrids by applying three criteria to define the hybrid that could be used to develop elite inbred lines quicker than others. 
A broad generalization covering all studies of the various types of gene action indicates that the complete dominance is more important than over dominance in the improvement of maize hybrids (Paterniani 1973). This implies that inbreeding depression is mainly due to the fixation of undesirable mutant genes that in hybrids are preserved by heterozygosity (Fasoulas 1988).

Table 2. The inbreeding depression (\%) in morphological traits of each maize hybrid.

\begin{tabular}{lllllll}
\hline Genotypes & $\begin{array}{l}\text { Days to } \\
\text { pollen shed }\end{array}$ & $\begin{array}{l}\text { Total } \\
\text { mean }\end{array}$ & $\begin{array}{l}\text { Ear height } \\
(\mathrm{cm})\end{array}$ & $\begin{array}{l}\text { Rows } \\
\text { /ear }\end{array}$ & $\begin{array}{l}\text { Ear length } \\
(\mathrm{cm})\end{array}$ & $\begin{array}{l}\text { Ears } \\
\text { /plant }\end{array}$ \\
\hline Hi Shell & 4.6 & 19.0 & 0.3 & 3.8 & 16.4 & 6.98 \\
DKC 7074 & 1.5 & 22.6 & 3.3 & 3.5 & 11.1 & 7.80 \\
PMZ 4 & 6.1 & 21.2 & 13.7 & 1.6 & 10.4 & 2.68 \\
\hline
\end{tabular}

Table 3. Grain yield (g/plant), GCA, SCA and heterosis in test crosses of each hybrid, the yield (\%) relative to CM $212 \times$ V 341 and yield of tester CM 212 in the same experiment.

\begin{tabular}{|c|c|c|c|c|c|}
\hline Genotypes & $\begin{array}{l}\text { Yield/plant } \\
\text { (g) }\end{array}$ & GCA & SCA & $\begin{array}{l}\text { Heterosis over } \\
\text { mid parent (\%) }\end{array}$ & $\begin{array}{l}\text { Yield relative to } \\
\text { CM } 212 \times \text { V } 341\end{array}$ \\
\hline Hi Shell & 649 & +28.0 & +75.0 & 124 & 211 \\
\hline DKC 7074 & 631 & 35.5 & 40.5 & 109 & 206 \\
\hline PMZ 4 & 1067 & +7.5 & 34.5 & 57 & 348 \\
\hline CM 212 & 340 & & & 111 & \\
\hline CM 212×V 341 & 307 & & & 100 & \\
\hline
\end{tabular}

The load of deleterious genes also affects combining ability. It is said that two inbred lines have good combining ability because favourable genes in one line complement the action of allelic and non-allelic genes in the other one and obscure their defects. In hybrids, the heterozygous condition obscures the depressive action of deleterious genes. These genes are thus accumulated in large amounts not allowing full exploitation of favorable additive alleles that are only partially expressed under heterozygous conditions. The components of variance for maize lines with general combining ability are mainly due to additive effects, whereas the components of variance for lines with specific combining ability are due to dominant effects (Sprague and Eberhart 1977). Hence, combining ability is related to heterosis because of the deleterious genes. Single cross hybrids with low inbreeding depression, positive general combining ability and negative specific combining ability have a desirable assemblage of genes that corresponds to an $F_{2}$ capable of developing elite inbred lines.

The present evaluation of single cross hybrids through mating designs revealed that the commercial hybrids PMZ 4 possesses desirable load of genes, due to low inbreeding depression (21.0\%), positive GCA (15.5\%) and negative SCA (34.5\%). Therefore, the $\mathrm{F}_{2}$ of PMZ 4 would be profitable germplasm for developing elite inbred lines.

\section{References}

Bauman LF 1981. Review of method used by breeders to develop superior corn inbreds. In: Proc. of Annual Corn and Sorghum Ind. Res. Conf. 36: 199-208.

Bernardo R 1996. Testcross selection prior to further inbreeding in maize. Mean performance and realized genetic variance. Crop Sci. 36: 867-871. 
Duvick DN 1984. Genetics contribution to yield gains in U.S. hybrid maize. pp. 15-47. In: W.R. Fehr (Ed.), Genetic contribution to yield gains of five major crop plants. Madison, W.I.: Crop Sci. Society of America.

Duvick DN 1996. Plant breeding, an evolutionary concept. Crop Sci. 6: 539-548.

Falconer DS 1989. Introduction to Quantitative Genetics. $3^{\text {rd }}$ Ed., pp. 438. Longman, London.

Fasoulas AC 1988. The Honeycomb Methodology of Plant Breeding. A.C. Fasoulsa, P.O. Box 1555, GR-54124, Thessaloniki 47, Greece, pp. 167.

Fountain MO and AR Hallauer 1996. Genetic variation within maize berreing populations. Crop Sci. 36: 26-32.

Hallauer AR 1979. Corn breeding opportunities in the 1980s. Des Moines, IA: Annual Corn Iowa Seed Dealers Association.

Hallauer AR 1990. Methods used in developing maize inbreds. Maydica 35: 1-16.

Jenkins MT 1978. Maize breeding during the development and early years of hybrid maize. pp. 13-28. In: D.B. Walden (Ed.), Breeding and Genetics. Proc. of the International Maize Symposium. John Wieley, New York.

Meghji MR, JW Dudley, RZ Lambert and GF Spraguev 1984. Inbreeding depression, inbred and hybrid grain yields and other traits of maize genotypes representing three ears. Crop Sci. 24: 545-549.

Paterniani E 1973. Recent studies on heterosis. pp. 1-22. In: R Moav (Ed.), Agricultural Genetics of Selected Topics. John Wieley, New York.

Russell WA 1991. Genetic improvement of maize yields. Advances in Agronomy 46: 245-298.

Sprague GF and SA Eberhart 1977. Corn Breeding. pp. 305-363. In: GF Sprague (Ed.), Corn and Corn Improvement. American Society of Agronomy, Madison, WI.

(Manuscript received on 10 April, 2013; revised on 7 November, 2013) 